\title{
SófALVI ANDRÁs*
}

\section{KIRÁLYKŐ VÁRA*}

\section{Kulcsszavak: Királykö, határvár, német lovagrend, nyillhegyek}

Nevezett várunk a Törcsvári-hágó havasalföldi oldalán, a történelmi határtól délre mintegy másfél kilométerre állt az Erdélybe vezető útvonal mentén, a Vár-patak völgye fölötti sziklaormon. A mai Podu Dâmboviţei (Argeş megye) település határában található várrom Cetatea Oratea vagy Cetatea Neamţului néven ismert, a vár és helyének emléke viszont az újkorra kikopott a magyar történeti hagyományból. Olyannyira, hogy a felkutatására indult Orbán Balázs a Kárpát-kanyarban, a Tatárhavas-hágón kereste és a Királyhegy közelében található vármaradványokkal azonosította Királykő várát. ${ }^{1}$

A vár elnevezése és a Törcsvári-átjárótól nyugatra magasodó Királykő-havas között egyértelmú ok-okozati összefüggés áll fenn, azt viszont már nehezen tudja kimutatni a történettudomány, hogy melyik középkori magyar uralkodó személyében kell keresnünk a vár és a hegység névadó ősét. Tény, hogy a törcsvári átkelőt évszázadokon keresztül Király útjának hívták, ez a megnevezés a 16-17. századi forrásokban többször előfordul. ${ }^{2}$ A magyar vár köznév -d képzős alakjából ('várad') kialakult Oratea névformával a 15-16. század fordulóján találkozunk először: Havasalföld vajdája, Radu cel Mare egy oklevélben arra kérte a brassóiakat, hogy az „Orății” hídjainál elfogott embereit bocsássák szabadon. ${ }^{3}$ Valószínű, ám korántsem bizonyos azonban, hogy a megnevezés mögött a királykői vár lappang, ugyanis a helynév gyakori a Kárpátokon kívül, Mikecs László több mint fél tucat előfordulását jegyezte fel a Havasalföldön 1845-ig fennálló Székely megye területén. ${ }^{4}$ (A Tömösi-szoros havasalföldi oldalán, Posada település fölött, a Prahova folyóba ömlő Orăţii patak szintén egy fontos, Erdélyt Havasalfölddel összekötő utat keresztez.)

Királykő vára a középkori írott forrásokban viszonylag későn jelenik meg, a fennmaradt oklevelek a 15. század elejétôl emlegetik az erősséget (a magyar megnevezés mellett a német

* Sófalvi András (1973), PhD, régész, Haáz Rezső Múzeum, Székelyudvarhely.

E-mail: sofalvi@hotmail.com

* A tanulmány a Bolyai János Kutatási Ösztöndíj BO/00303/15/2 sz. pályázatának támogatásával készült.

1 Lásd Orbán Balázs: A Székelyföld leírása történelmi, régészeti, természetrajzi s népismei szempontból. VI. Bp., 1873. 77-80.

2 1533: „via publica ac regia Terch”. Székely oklevéltár. V. (1296-1603). Szerk. SzÁdeczKy Kardoss Lajos. Kvár, 1896. 52; 1611: „a Király-után Rakat felöl”. HIDVÉGI Mikó Ferencz bistóriája (15941613) = Gr. Illésházy István nádor fóljegyzései (1592-1603) és Hidvégi Mikó Ferencz históriája (15941613). Közli Kazınczy Gábor. Pest, 1863 (Monumenta Hungariae Historica. Scriptores. VII). 198-199.

3 Ioan Bogdan: Relațiile Țării Românești cu Brașovul și cu Țara Ungurească în sec. XV. și XVI. I. 14131508. Buc., 1905. 228.

4 Mikecs László: $A$ Kárpátokon túli magyarság = Magyarok és románok. I. Szerk. DeÉR József-GÁLDI László. Teleki Intézet, Bp., 1943 (A Magyar Történettudományi Intézet Évkönyve 1943). 455. 
Königstein, illetve a latin Lapis Regis szintén előfordul). A Luxemburgi Zsigmond elleni felkelés idején a várat a pártütők táborához tartozó királykői várnagy, Tuzsoni Bolgár Miklós tartotta kezében, aki végül azt 1404. március 22-én adta fel. ${ }^{5}$ 1427-ben Zsigmond király a vár alatt keltezett oklevelet. ${ }^{6}$ 1435-től van az első adat arra, hogy e távoli erődítmény a székely ispáni honor tartozéka; ekkor Kusalyi Jakcs Mihály székely ispán puskaport kért a brassóiaktól Törcsvár és Királykő várnagyai részére. ${ }^{7}$ 1443-ban a várat Hunyadi János és Újlaki Miklós székely ispánok birtokai közt találjuk. Ôk megújították a Havasalfölddel kereskedő brassóiak és a barcaságiak kiváltságait, szabályozva a vámtételeket, és megparancsolták a törcsvári és királykői várnagyaiknak („vobis castellanis nostris castrorum Thercz et Keralkew”), hogy e szabadságjogokat tartsák tiszteletben. ${ }^{8}$ A várat 1457 -ben a Hunyadiak kezén lévő királyi várak közt sorolták fel. ${ }^{9}$ 1460. június 3-án Mátyás király megparancsolta Brassó városának, hogy Törcs, Királykő és Höltövény várakba szállítson száz aranyforint értékben élelmiszert, mivel azok a korábbi székely ispánok hanyagsága miatt ellátás nélkül maradtak. ${ }^{10}$ Felsorolásunk szolgáljon egy régész mentségéül - kimerül a középkori oklevéltárakban közzétett dokumentumok áttekintésében, továbbá Engel Pál nagyszabású világi archontológiájának felső időhatárával, valamint Kordé Zoltánnak a székely ispáni méltóság történetét taglaló disszertációja korszakhatárával. Az idézett forrásokból két alapvető észrevétel adódik. Királykő várát mint a dél-, délkelet-erdélyi határvédelem egyik kulcsfontosságú erődítményét 1435-től a székely ispánok kezén találjuk. A számba vett források szinte kivétel nélkül együtt emlegetik a királykői várat Törcs várával, sőt egy 1535-ben kelt számadáskönyvi bejegyzés pontosít a vár lokalizálásában, földrajzilag Törcsvár „fölé”, azaz egy jól ismert határváron kívül helyezve azt („pro praeparatione pontis olim Lapidis Regis dictae in Alpibus, supra castrum Thewrcz existentem"). ${ }^{11} \mathrm{E}$ perdöntőnek minősülő bizonyíték és az alapján, hogy a két vár lényegében a Törcsvári-hágó végpontjain található, sikerült Engel Pálnak kétséget kizáróan azonosítania az írott forrásokban megjelenő erôsséget a Királykő havasának lábainál fekvő várrommal. ${ }^{12}$ A királykői vár régészeti kutatásában részt vevô Gheorghe I. Cantacuzino román régész Walter Horwath szász történész nyomán szintén erre a felismerésre jutott. ${ }^{13}$

Lássuk közelebbről a várat és környezetét! A déli irányba kinyíló völgyre (Valea Orăţii) néző vár alaprajza szabálytalan rombusz alakú, észak-dél irányban mért hossza $30 \mathrm{~m}$, keletnyugati irányú tengelye pedig mintegy 20 m. A durván megmunkált mészkőtömbökből bar-

5 Engel Pál: Magyarország világi archontológiája 1301-1457. I. História-MTA Történettudományi Intézete, Bp., 1996 (História Könyvtár. Kronológiák, Adattárak 5). 341.

6 „Datum sub castello nostro Kiralku vocato”. Lásd Kordé Zoltán: A székely ispáni méltóság története a kezdetektól 1467-ig. PhD-értekezés (Kézirat). Debrecen, 2003. 29.

7 Urkundenbuch zur Geschichte der Deutschen in Siebenbürgen. I-VII (1191-1486). Hrsg. Franz ZIмmermann-Carl Werner-Georg Müller-Gustav Gündisch-Herta Gündisch-Gernot Nussbächer-Konrad G. GüNDIsch. Verein für Siebenbürgische Landeskunde-Verlag der Rumänischen Akademie, Hermannstadt-Buk., 1892-1991 (a továbbiakban Ub). IV. 579; KoRdÉ: i.m. 29 .

8 Ub V. 106-107; Kordé: i. m. 35.

9 ENGEL: i.m. 341.

10 KORDÉ: i. m. 43.

11 Rechnungen aus dem Archiv der Stadt Kronstadt. II. Rechnungen aus 1526-1540. Kronstadt, 1889 (Quellen zur Geschichte der Stadt Kronstadt in Siebenbürgen). 323.

12 ENGEL: i. m. 341.

13 Gh. I. Cantacuzino: Cetăţi medievale din Ţara Româneascâ (sec. XIII-XVI). Buc., 1981. 130. 
nássárga, apró kavicsos, mészrögös habarcsba rakott falak 4-5 m magasan állnak ma a déli és keleti oldalakon (falvastagság: 2,60 m). Az erősen meredek, sziklás nyugati oldalon falnak nincsen nyoma, a falazat északnyugati és délnyugati sarka lekerekített. A keleti oldalon félkör alakban a várbelső felé nyitott torony ugrik ki a falazatból, azzal szerves egységet alkotva (nyílásszélessége 3,60 m). A romos állapotú faltorony falszövetében a délkeleti oldalon utólag elfalazott ablak- vagy lőrésnyílás fedezhető fel (belső magassága meghaladja az $1 \mathrm{~m}$-t, szélessége 70-80 cm). Délen, a délkeleti saroktól egyharmadnyi hosszúság után a fal 0,80 m kiugrással megvastagodik.

A vár területén két szögletes formájú, sziklába vésett objektum ismerhető fel, kőépületnek nem maradt nyoma. Az erősséget északkeletről indulva, majd ívelten a keleti oldalon folytatódva, sziklába ásott szárazárok határolja, melynek szélessége 7-8 m, mélysége 1,5-2 m. A vár délkeleti sarkától az árok tovább folytatódik délnyugati irányban egészen a meredek sziklaperemig; az árok fölött feltehetően felvonóhíd vezetett át a vár déli oldalán kialakított, sziklába vésett útra, amelyen a bejáratot lehetett megközelíteni.

A Hosszúmező (Câmpulung, Argeş megye) felől Törcsvárra tartó, Havasalföldről Erdélybe érô útvonal a vár nyugati oldalán, annak kimagasló sziklája alatt 35-40 m-rel kapaszkodott fel, az út sziklába mélyedő nyomvonala máig jól követhető (bevágódó keréknyomok). Valahol emellett kellett állnia annak a középkori vámhelynek, amelynek felügyeletét és ellenőrzését a vár látta el.

Királykő várának területén archeológiai jellegű kutatás először 1905-ben folyt Grigore Tocilescu régész kezdeményezésére. A mai szemmel nézve meglehetősen szakszerűtlen módszerekkel végzett feltárás során alaposan megbolygatták az erősség belső területét és annak sztratigráfiáját, a felszínre került leletek pedig kontextus nélkül kerültek begyüjtésre. ${ }^{14}$ Már ekkor nagy mennyiségű fémtárgy: vas nyílcsúcsok (egy részük a vár délkeleti, belső oldalán feltárt, elszenesedett gerendák maradványaiba szorulva látott napvilágot), vasékek, kardtöredékek, patkók, sarkantyúk, csatok, kések, szögek kerültek elő, továbbá néhány kő ágyúgolyó, valamint kerámia- és kályhacsempe(?)-darabok. Az északkeleti oldalon napvilágra bukkant, sziklába ásott, kör alakú, homokkőből falazott, alján agyagréteggel ledöngölt ciszterna (mélysége 5,35 m, átmérője 3,40 m) - melynek szúk, összeboltozott szájnyílást képeztek ki - a '70-es évekre nagyrészt elpusztult. Nyomtalanul eltűnt azóta az a falrészlet is, melyet a váron kívül, a déli oldalon található sziklaplatón emeltek (feltehetően a bejárat fedezésére).

Újabb feltárásokra 1968-1969-ben és 1971-ben került sor bukaresti és pitești-i intézmények együttműködésével, Alexandrina $\mathrm{D}$. Alexandrescu régész irányításával. ${ }^{15}$ Mindezek során leírások születtek a falak szerkezetét, építési technikáját és a bejárat elhelyezkedését illetően, valamint a várbelsőben észlelt jelenségekről stb. Az emplekton jellegű falazatot a letisztított sziklára emelték, előtte a felszínt elegyengették. A megfigyelések szerint a várba vezető

14 A közöletlen ásatás eredményeiről (kéziratos jegyzetek a Román Tudományos Akadémia bukaresti könyvtárában, Ms. 5137) Gh. I. Cantacuzino könyvéből tájékozódhatunk. Lásd CANTAcuzıno: i. m. 120-124.

15 Az ásatás a bukaresti Régészeti Intézet (Institutul de Arheologie), a Történeti Múzeum (Muzeul de Istorie), a Hadtörténeti Múzeum (Muzeul Militar Central), a Múemlékek Igazgatósága (Direcția Monumentelor Istorice), és a Pitești-i Múzeum (Muzeul Județean Argeș) együttmúködésével folyt (az ásatásvezető mellett részt vevő régészek: Anca Păunescu, Gh. I. Cantacuzino, Lucian Chițescu, Spiridon Cristocea). 
bejáratot a déli oldalon alakították ki, a délkeleti sarok belső oldalától mintegy 4 m-re (a falkiugrásnak megfelelő helyen) - a faszerkezet nyomai a sziklafelszíntől 1 m magasságban, 2 m szélességben voltak megfoghatók. Az újabb leletek nagyrészt másodlagos helyzetből kerültek elő a vár belső területén, illetve a várárokban: további nagy mennyiségü fémtárgy (a néhány soros előzetes közlemény 200 darab fölötti /!/ nyílcsúcsot említ $\left.{ }^{16}\right)$, középkori, a 14. század második felétől keltezhető kerámiatöredékek és két havasalföldi pénzérme (Mircea cel Bătrân veretei) a sziklafelszín fölötti földrétegbool ${ }^{17}$ (a megyei repertórium ezeken kívül további négy darab 14-15. századi havasalföldi pénzérméről tesz említést). ${ }^{18}$ A régészeti leletek tanúsága szerint a vár a 16. századig volt használatban.

Az ásatás tudományos igényű közlése elmaradt, így a feltárási eredményeket röviden taglaló könyvfejezet nélkül középkori régészetünk szegényebb volna egy várral. Ugyanakkor nem először fordul elő a régészet kelet-, délkelet-európai történetében, hogy az ásatási rajzok, fényképek és a leletanyag teljesen publikálatlanok maradtak. Sajnos, a dokumentációt és a kerámialeleteket a mai napig nem sikerült megtalálni a kutatásokban részt vett intézmények archívumában/gyüjteményében, mindössze a pitești-i múzeumban leltárba vett fémtárgyak tanulmányozására volt lehetőségem a közelmúltban. ${ }^{19}$ Dokumentálódásom során 206 fémleletet tudtam azonosítani a királykői vár 1968-1969. évi ásatásaiból, egy-két lelet kivételével ezek mind vasból kovácsolt fegyverek és használati eszközök, tárgyak (nyílcsúcsok, kardkoptatók, patkók, sarlók, kések, olló, tük, csat, szögek, kapcsok). ${ }^{20}$ A tanulmányozott 40 darab, íjhoz, illetve számszeríjhoz való nyílhegyek közt az előbbiek sorában nyéltüskés és nyélcsöves, rombikus, deltoid, levél formájú és szakállas, illetve háromélű típus egyaránt előfordul, melyek a többi fémanyaggal együtt jelentős részben a 14-15. századra keltezhető tárgytípusokat képviselnek, megerősítve a feltárást végző régészek megállapítását a vár építésére és működésére nézve.

A történeti források és a tanulmányozott régészeti leletek, valamint a topográfiai megfigyelések alapján kísérletet tehetünk a királykői vár építéstörténetének feltárására és funkciójának meghatározására. A várhely földrajzi pozíciója a Törcsvári-hágó bejáratánál nem hagy kétséget afelől, hogy az a délről, azaz Havasalföldről Erdélybe tartó katonai-kereskedelmi forgalmat volt hivatott ellenőrizni. Az is megállapítható, hogy az előretolt helyőrség a középkori Magyar Királyság hegyeken túli megfigyelőállása volt, és nem a havasalföldi vajdák építették. A források tanúsága szerint vám is múködött a várban vagy a vár alatt. A közeli Rukkoron (Rucăr, Argeș megye) állt a havasalföldi vám. ${ }^{21}$ Királykő várának létesítése összefügghet az erdélyi telepesek Árpád-kor végétől kimutatható havasalföldi megjelenésével és terjeszkedésével (Câmpulung, Curtea de Argeș), melynek egyik legékesebb bizonyítéka a

16 Studii și Cercetări de Istorie Veche 21(1970). nr. 3. 516. Vö. Cantacuzino: i. m. 124.

17 Studii și Cercetări de Istorie Veche 20(1969). nr. 3. 497.

18 Dragoș Măndescu-Ion Dumitrescu-Marius Păduraru: Repertoriul arheologic al județului Argeș. Brăila, 2014. 146.

19 A leletek tanulmányozásáért Dragoș Măndescu régésznek tartozom köszönettel, aki önzetlenül rendelkezésemre bocsátotta a királykői várnak az intézményben őrzött leletanyagát, és lehetővé tette közlésüket.

20 A múzeum gyújteménye a leltárkönyv szerint 249 fémből készített régészeti leletet ôriz a várból, ebből 74 nyílhegy és/vagy számszeríjhoz való kovácsolt hegyként van nyilvántartva (1. sz.: 570-612, 1290-1486).

21 Cantacuzino: i. m. 126. 
Hosszúmezőn talált, Lőrinc ispán (comes Laurentius de Longo Campo) 1300 körülre datált sírköve. ${ }^{22}$ A havasalföldi vajdaság megalapításával Királykő vára túlságosan ki volt téve a közeli Câmpulungon székelő román vajdák támadásainak. Küküllei János krónikájában azt találjuk, hogy Nagy Lajos király „a havasalföldi határnál az igen erös Törcs-várát épitette fel, és fegyveres hadinéppel, angol könnyü fegyverzetúekkel és számszerijászokkal erösitette meg a várôrséget". ${ }^{23}$ Törcsvár 1377-ben elkezdett építésekor a király megígérte Brassó városának, hogy a rukkori vámot Törcsvárra fogja áthelyeztetni - az oklevél e részlete közvetett tanúsága a vámot felügyelő királykői vár létének. ${ }^{24} \mathrm{~A}$ kulcsfontosságú helyen álló erősséget a régészeti leletek tanúsága szerint komoly ostromok érték, és nem kizárt, hogy időszakonként havasalföldi kézre került a 14-15. században. Az Oszmán Birodalom megjelenése, majd nyomasztó katonai jelenléte és támadásai a térségben a 15. századtól Erdélyt sem kímélték, ugyanakkor a mohácsi csata és következményei egyre kevésbé tették lehetővé egy ilyen exponált, „végeken túli vár" fenntartását, és már kísérlet sem történt a vár hadászati korszerűsítésére a 16. században. A század közepén Erdélynek Habsburg-tartománnyá való átalakítására kiküldött királyi biztosok 1551-1553 között végzett előkészítő tevékenysége - mely több határszéli vár és város megerődítését érintette - nem foglalkozott a királykői várral. ${ }^{25} \mathrm{Az}$ Erdélyi Fejedelemség megszületése körüli nehéz évtizedekben az erősség feltehetően kikerült az erdélyi politika hatósugarából, és az aktív katonai védelem a továbbiakban teljesen Törcsvárra tevődött át.

Tanulmányom végéhez közeledve egy vargabetűvel visszatérnék a királykői vár kezdeteinek kérdéséhez. Noha a kutatók többsége az elmúlt évtizedekben leszámolt a lehetôséggel, e sorok írója mégis veszi a bátorságot arra, hogy Királykő várát visszaemelje a német lovagrendi várak közé, melyek azonosítása körül máig sok a bizonytalanság. Mint a korabeli oklevelekből megtudjuk, 1211-ben II. András magyar király a Szentföldön működő Szűz Mária-ispotály keresztes lovagjainak adományozta a Barcaságot, azzal a céllal, hogy országát gyarapítsák és a kunok ellen védelmezzék. A német lovagrend hamarosan földvárakat, majd kővárakat emelt területén, melyekből egy a hegyeken kívül épült. Mivel a lovagok egyre kevésbé tartották magukat a királlyal kötött egyezményhez, II. András elvette, majd rövidesen (1222-ben) viszszaadta a lovagok erdélyi birtokait, és további havasokon túli területeket adományozott nekik, ahol ók újabb várat építettek (castrum munitissimum ultra montes nivium), mely sikerrel állt ellen a kunok ostromának. ${ }^{26} 1225$-ben a király személyesen vezetett hadat a lovagok ellen, a havasokon túl épített várukat elfoglalta, és a lovagrendet véglegesen kiűzte a Magyar Királyságból. ${ }^{27}$

22 E. LĂZĂRESCU: Despre piatra de mormânt a comitelui Laurențiu și câteva probleme arheologice și istorice în legătură cu ea. Studii și Cercetări de Istorie Veche și Arheologie 4(1975). nr. 1-2. 109-126.

23 Idézet a Thuróczy-krónikában fennmaradt szövegvariánsból. THuRóczy János: A magyarok krónikája. Ford. Honváth János. Európa, Bp., 1980. 262.

24 Ub II. 480.

25 Овокnі Teréz: Erdély pénzügyei I. Ferdinánd uralma alatt 1552-1556. Szentpétery Imre Történettudományi Alapítvány, Bp., 2002 (Fons Könyvek 1). 147-243. Lásd még Barabás Samu: Erdély történetére vonatkozó regeszták. Történelmi Tár 1891. I. közl. 431-432; II. közl. 645-659; 1892. III. közl. 143-158.

26 Erdélyi okmánytár. Oklevelek, levelek és más írásos emlékek Erdély történetéhez. I. 1023-1300. Bevezető tanulmánnyal és jegyzetekkel regesztákban közzéteszi JAкó Zsigmond. Akadémiai, Bp., 1997 (A Magyar Országos Levéltár kiadványai II. Forráskiadványok 26). 161. sz.

27 Uo. 135. sz. 
A Kárpát-kanyarban található középkori vármaradványok topográfiájának tanulmányozása közben jutottam arra a felismerésre, hogy Királykő vára az egyetlen olyan - romjaiban fennmaradt - erősség, amelyre ráillik a német lovagrend havasokon túl épített várának képe. A nem elôzzmények nélküli feltevést ${ }^{28}$ viszont éppen a régészeti feltárások cáfolták meg. Azonban ismerve a vár régészeti kutatástörténetét, csak fenntartásokkal tudjuk elfogadni az erősség létrejöttére, építésére vonatkozó megállapításokat, ugyanis az 1968-ban elkezdett feltárások már nem találtak intakt rétegeket a várban, és lényegében csupán az 1905-ben kiszórt leleteket tudták begyújteni. Minden jel arra vall, hogy ezek egy részét ráadásul kiselejtezték, és a megmaradt kerámialeletek valahol lappanganak, vagy elpusztultak. A jelentős mennyiségủ fegyverlelet (főként nyílcsúcsok) elsődleges tipológiai vizsgálata és elemzése alapján már előzetesen megállapítható, hogy a legkorábbi darabok (rombikus formájú és rövid vágóélü szakállas nyílhegyek) nem zárják ki a várépítés 14. századnál korábbi keltezésének lehetőségét. Mindemellett, a keleti oldalon emelt félköríves faltorony véleményem szerint eredetileg a kápolna szerepét is betölthette a várban, délkeleti oldalán elfalazott ablak/lőrés nyomaival. A vár alaprajzának vizsgálata nem nyújt biztos fogódzót e tekintetben, ugyanis a német lovagrend várépítészetére jellemző sajátosságok csak később, a Baltikumban alakultak ki.

Királykő vára több szempontból figyelemre érdemes, és sajnos a méltatlanul elfelejtett váraink közé tartozik. Egyike azon előretolt helyőrségeknek, melyek a Magyar Királyság középkori expanziójának idején a Kárpátok külső oldalán épültek. Építéstörténete ma még jórészt feltáratlan, leletei közöletlenek. Rövid tanulmányomban egy fehér folt kiszínezésére tettem kísérletet, többek közt újraelemezve a lovagrendi építés lehetőségét.

\section{KING'S STONE CASTLE}

\section{Keywords: King's Stone, border castle, Teutonic Order, arrowheads}

The King's Stone Castle (known by the resident population as 'Oratea') is situated under the mountain with the same name near the exit of the road that leads from the Bran Pass to Muntenia in the outskirts of Podu Dâmboviței village (Argeș county).

The castle, mentioned for the first time at the beginning of the $15^{\text {th }}$ century as a royal fortification, after several decades came into the possession of Szekler comes. According to the historical documents it was used till the $16^{\text {th }}$ century, fact proved by the results of archaeological researches made between 1968-1969 and 1971, too. The archaeological finds coming out from secondary position and kept today in the collection of Argeș County Museum (Pitești town) are composed of iron objects, with a significant number of arms (for instance 40 arrowheads), confirming the assaults suffered by the castle in the 14$15^{\text {th }}$ centuries.

The fortification's dimensions are very modest, having a layout of an irregular rhombus form with a semicircle tower on the eastern side and encircled by a ditch dug into the stone on the eastern side. The entrance of the castle was established on the southern side; two spaces dug into the stone were discovered inside the castle.

28 A nézet egyik legelső képviselője a szász Walter Horwath volt. Lásd W. Horwath: Die Burg bei Rucăr. Die Erbauung der Burg = Das Burzenland IV/1. Die Dörfer des Burzenlandes. Hrsg. E. JEKELıus. Burzenländer Sächsisches Museum, Kronstadt, 1929. 56-62. 
By the analysis of the topographical position of the castle we can draw the theory that King's Stone Castle is the only fortification outside the Carpathian Mountains known today which corresponds with the contemporary descriptions referring to the fortification built by the Teutonic Order. This theory isn't excluded from archaeological point of view either; as certain early type arrowheads (with rhombus and barbed forms) could confirm our opinion.

\section{CETATEA PIATRA CRAIULUI}

\section{Cuvinte-cheie: Piatra Craiului, cetate de graniță, Ordinul Teutonic, vârfuri de săgeată}

Cetatea Piatra Craiului (cunoscută de localnici sub numele de Oratea) se află la poalele muntelui cu același nume, la ieșirea drumului din pasul Bran spre Muntenia, în hotarul satului Podu Dâmboviței (jud. Argeș).

Menționată în izvoarele istorice de la începutul secolului al XV-lea ca cetate regală, după câteva decenii fortificația ajunge în posesia comitelui secuilor. Documentele istorice atestă faptul că cetatea era folosită până în secolul al XVI-lea, fapt relevat și de rezultatele cercetărilor arheologice efectuate în anii 1968-1969 și 1971. Materialul arheologic provenit din poziții secundare și păstrat în colecția Muzeului Județean Argeș (Pitești) este format din obiecte de fier, dintre care un număr însemnat de arme (de ex. 40 vârfuri de săgeți) mărturisesc asediile suferite în cursul secolelor XIV-XV.

Fortificația are dimensiuni destul de modeste, având un plan romboidal neregulat; are un turn semicircular pe partea estică, fiind înconjurat dinspre est cu un șanț săpat în stâncă. Accesul în cetate era posibil pe latura din sud. În interiorul cetății au fost observate două încăperi săpate în stâncă, respectiv o cisternă.

În urma analizei amplasării și topografiei cetății se poate lansa ipoteza conform căreia cetatea Piatra Craiului este singura fortificație cunoscută în zilele noastre care corespunde cu descrierea cetății ridicate de Ordinul Teutonic în exteriorul Munților Carpați. Ipoteză noastră poate fi sprijinită și de argumente arheologice, anume de vârfurile de săgeți timpurii cu forme romboidale și cu barbă descoperite în urma săpăturilor de la Piatra Craiului.

\section{KÉPJEGYZÉK/LIST OF ILLUSTRATIONS/LISTA ILUSTRAȚIILOR}

1. A Törcsvári-hágó délről, Királykő várának sziklaormával (a szerző felvétele)/Bran Pass from the south, with the rock of King's Stone Castle (photo taken by the author)/Pasul Bran dinspre sud, cu stânca cetăţii Piatra Craiului (fotografia autorului)

2. Királykő várának romjai délkeletről (a szerző felvétele)/Ruins of the King's Stone Castle from the south-east (photo taken by the author)/Ruinele cetăţii Piatra Craiului dinspre sud-est (fotografia autorului)

3. A faltorony délkeleti oldalán elfalazott nyílás belülról (a szerző felvétele)/Opening blocked at the south-east side of the semicircle tower from inside (photo taken by the author)/Deschidere zidită pe latura sud-estică a turnului semicircular dinspre interior (fotografia autorului)

4. A vártól nyugatra haladó út nyomvonala a sziklafelszínen (a szerző felvétele)/The road westward from the castle on the rock surface (photo taken by the author)/Traseul drumului aflat la vest de cetate pe suprafaţa stâncii (fotografia autorului)

5. Királykő várának alaprajza (Karczag Ákos-Szabó Tibor: Erdély, Partium és a Bánság eröditett helyei. Várak, várkastélyok, városfalak, templomvárak, barlangvárak, sáncok, eródítmények a honfoglalástól a 19. század végéig. Bp., 2012. c. múve nyomán)/The ground plan of the King's Stone Castle (by the volume Karczag Ákos-Szabó Tibor: Erdély, Partium és a Bánság eröditett helyei. Várak, várkastélyok, 
városfalak, templomvárak, barlangrárak, sáncok, eródítmények a honfoglalástól a 19. század végéig. Bp., 2012.)/Planul cetăţii Piatra Craiului (după volumul Karczag Ákos-Szabó Tibor: Erdély, Partium és a Bánság eröditett helyei. Várak, várkastélyok, városfalak, templomvárak, barlangruárak, sáncok, eröditmények a honfoglalástól a 19. század végéig. Bp., 2012.)

6. Királykő vára az I. katonai felmérésen (I. katonai felmérés. Erdély. Hadtörténeti Intézet és Múzeum Térképtára, Bp., Jelz.: B IXa 1123. Lépték: 1:28.800)/King's Stone Castle on the military survey I. (Military Survey I. Transylvania. Institute and Military Museum in Budapest. Score: B IXa 1123. Scale: 1:28.800)/Piatra Craiului pe harta militară I. (Harta militară I. Transilvania. Institutul şi Muzeul Militar din Budapesta. Cota: B IXa 1123. Scara: 1:28.800)

7. a-c. Nyílhegytípusok a királykői vár 1968-1969. évi feltárásairól (a szerző felvételei)/Arrowhead types coming from King's Stone Castle excavations, 1968-1969 (photos taken by the author)/ Tipuri de vârfuri de săgeţi descoperite în urma săpăturilor arheologice de la cetatea Piatra Craiului din anii 1968-1969 (fotografiile autorului) 


\title{
KÉPMELLÉKLET
}

\author{
SÓFALVI ANDRÁS
}

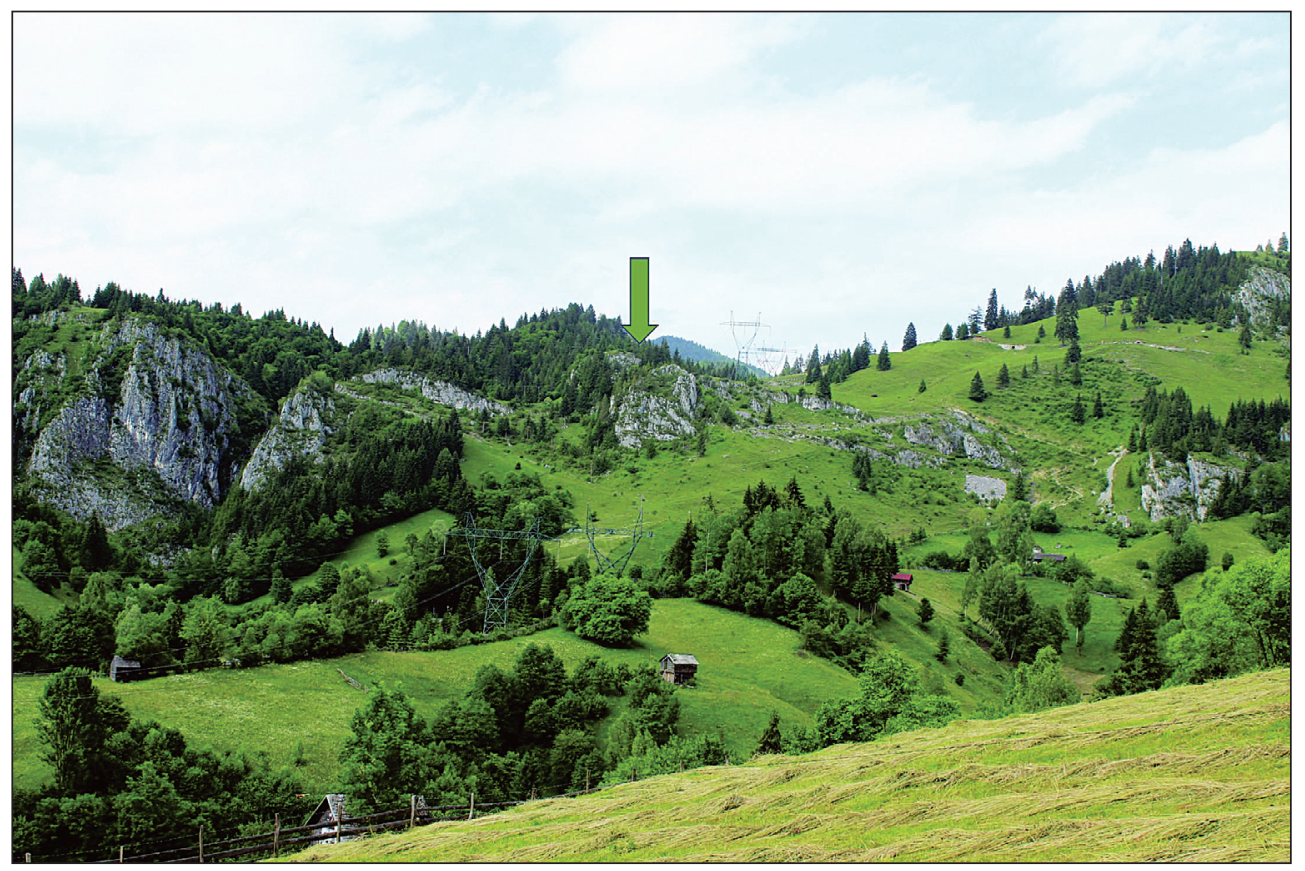

1. 
Sófalvi András

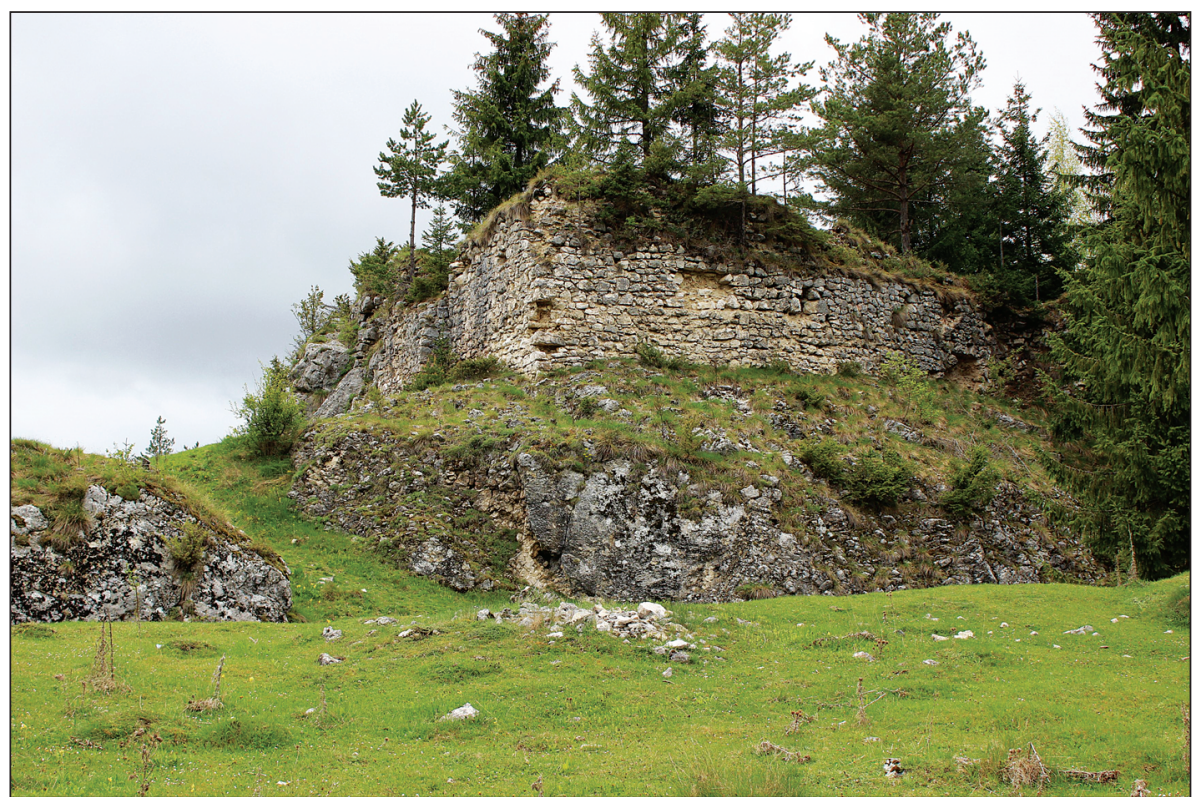

2.

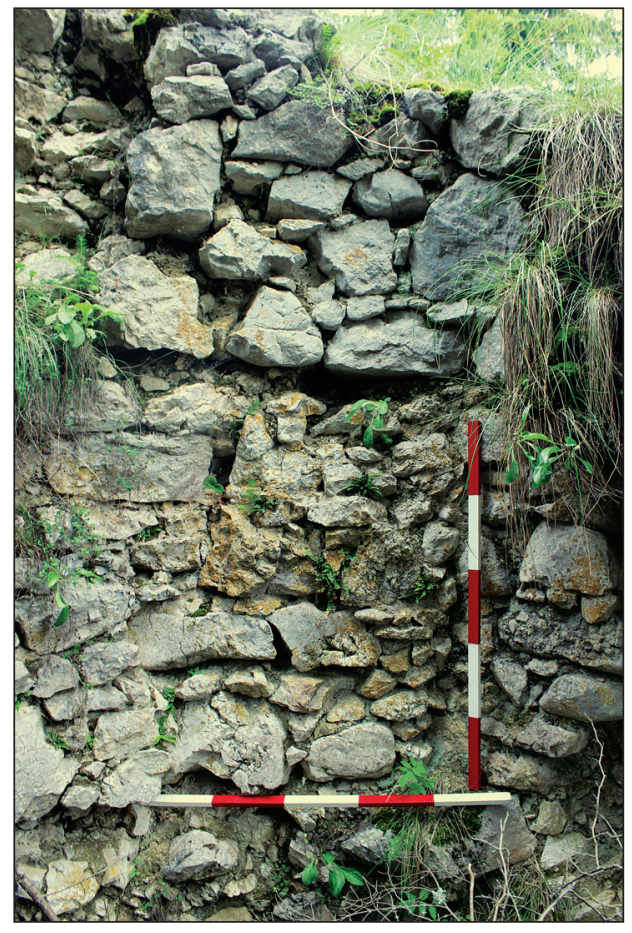

3.

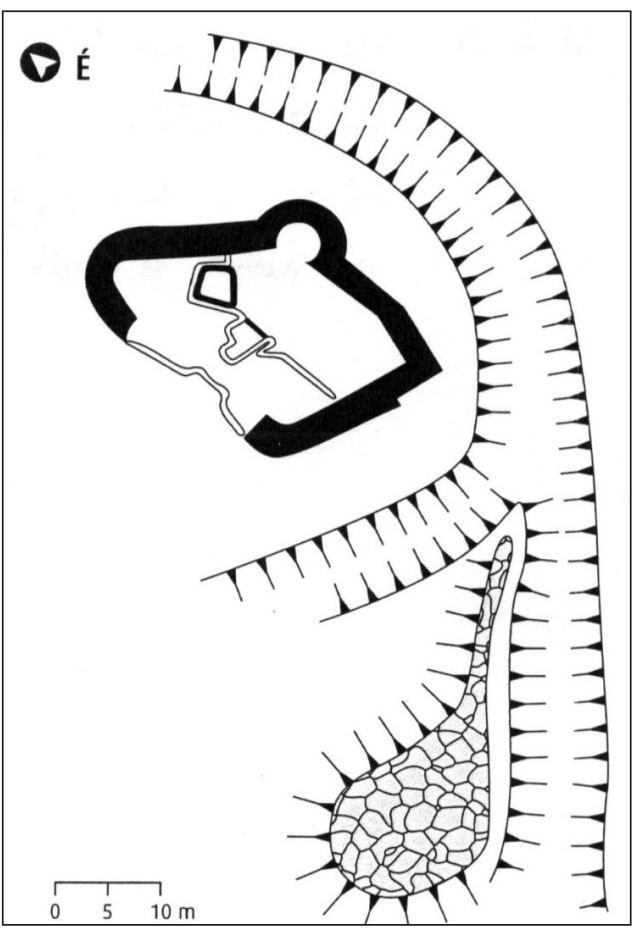

5 . 


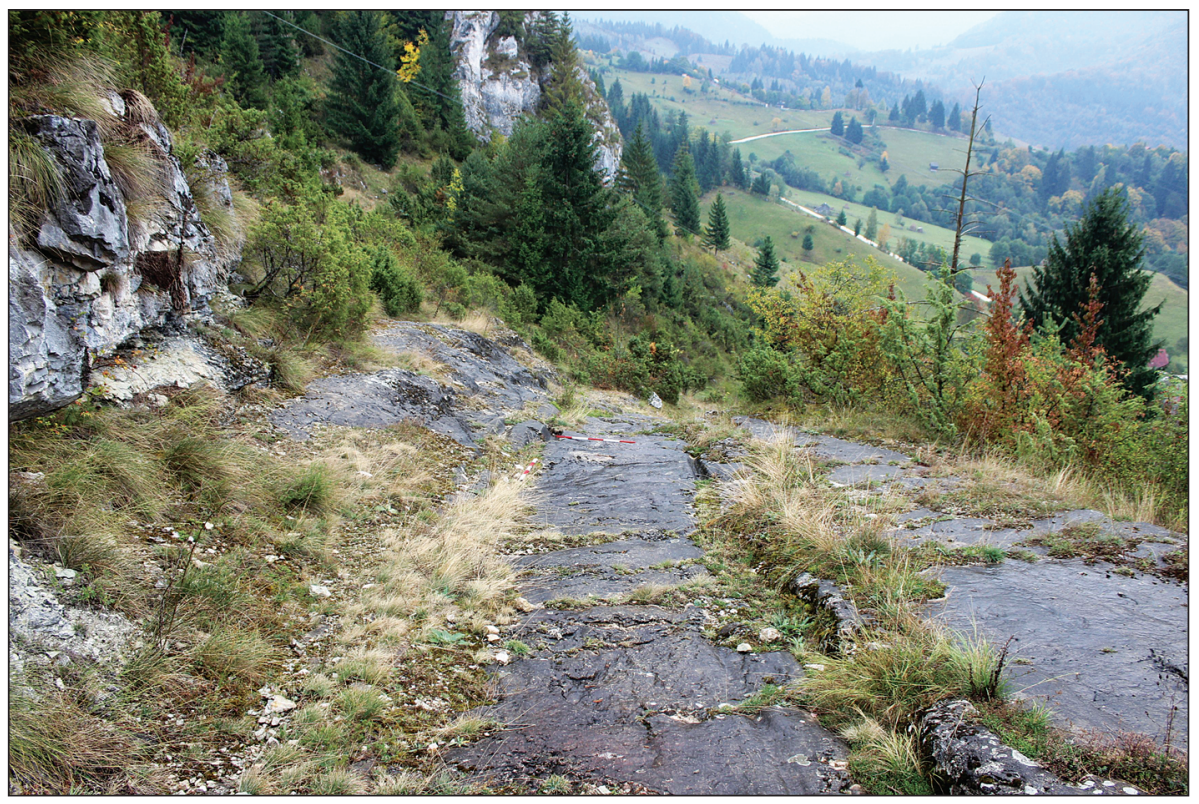

4.

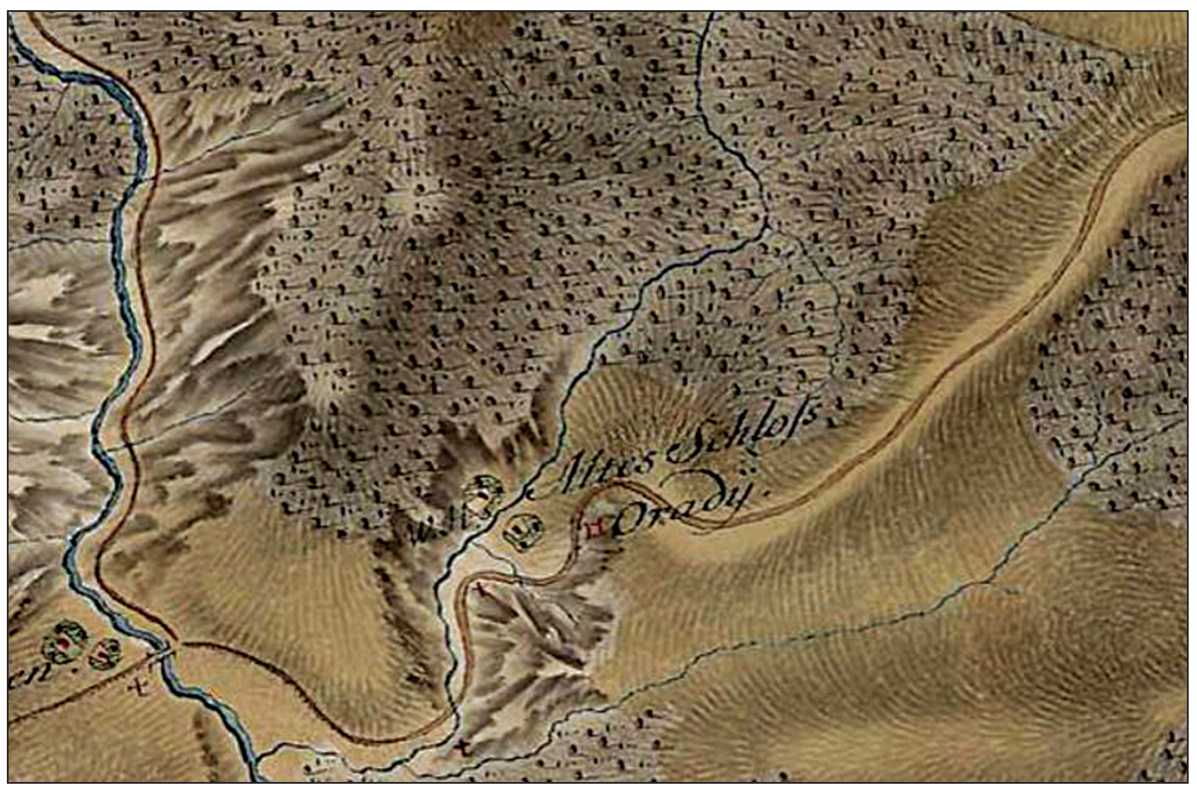

6. 
Sófalvi András
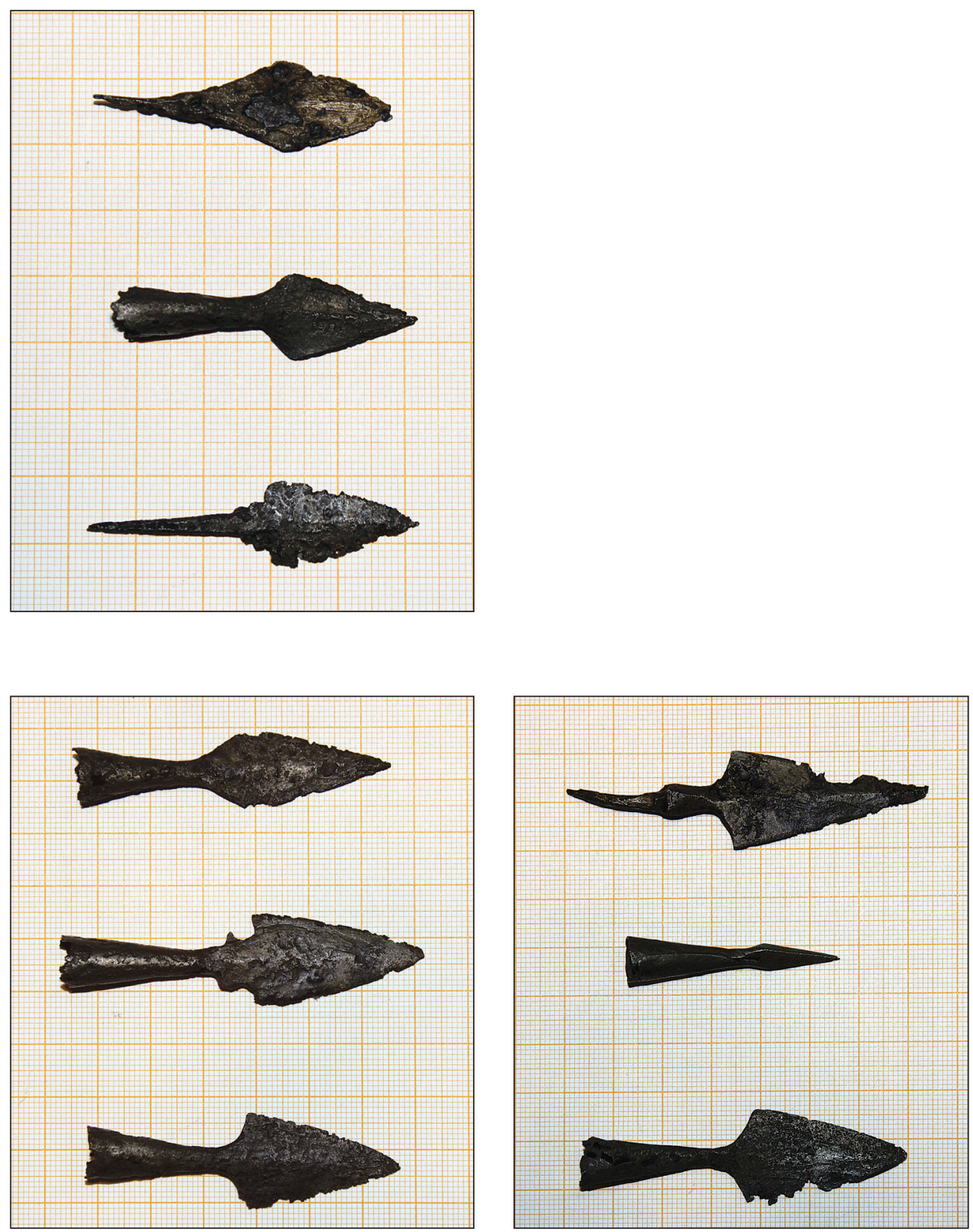

7. $a-c$ 